\title{
Protein methylases in Trypanosoma brucei brucei: activities and response to DL- $\alpha$-difluoromethylornithine
}

\author{
Nigel Yarlett, ${ }^{1 *}$ Aaron Quamina ${ }^{2}$ and Cyrus J. BaCCHI ${ }^{1}$ \\ ${ }^{1,2}$ Haskins Laboratories and Departments of Biology ${ }^{1}$ and Chemistry ${ }^{2}$, Pace University, New York, NY 10038, USA
}

\begin{abstract}
Protein methylases I, II and III were detected in extracts of Trypanosoma brucei brucei, and characterized according to the specific amino substituent methylated. Only protein methylase II activity was elevated by difluoromethylornithine treatment of $T$. b. brucei, and hence this enzyme was characterized further. Protein methylase II transferred methyl groups from $S$-adenosyl-L-methionine ( $S$-AdoMet) to the carboxyl residues of several protein substrates, exhibiting highest activity with histone VIII-S (arginine-rich subgroup $f_{3}$ ). The crude enzyme had an apparent $K_{\mathrm{m}}$ for histone VIII-S of $28 \mathrm{mg} \mathrm{ml}^{-1}(11.4 \mathrm{mM}$-aspartyl and $18.4 \mathrm{mM}$-glutamyl residues methylated), and an apparent $K_{\mathrm{m}}$ for $S$-AdoMet of $8.4 \mu \mathrm{M}$. T. b. brucei protein methylase II was sensitive to inhibition by $S$-adenosyl-L-homocysteine and its analogue sinefungin with apparent $K_{\mathrm{i}}$ values of 12.9 and $1.6 \mu \mathrm{M}$, respectively. Using a partially purified preparation, analysis of kinetic data in the presence and absence of sinefungin indicated that this analogue acts as a competitive inhibitor of the $S$-AdoMet binding site, and as a noncompetitive inhibitor of the (protein) histone VIII-S binding site. The possible role of the enzyme in morphological control and its potential as a chemotherapeutic target are discussed.
\end{abstract}

\section{Introduction}

$S$-Adenosyl-L-methionine ( $S$-AdoMet) is the methyl donor for many methylation reactions resulting in the formation of $S$-adenosyl-L-homocysteine ( $S$-AdoHcy: Fig. 1). The ratio of substrate to product (methylation index) plays a central role in the control of methylation reactions (Ueland, 1982). Methylation is a reversible pathway for post-translational protein modification, resembling the process of protein phosphorylation (Kim, 1977; Paik \& Kim, 1980). The multi-faceted roles of protein methylation include chemotactic sensitization, hormone storage and secretion, repair of aged proteins, modification of calmodulin sensitivity to calcium, and control of DNA-histone association (van Waarde, 1987; Paik \& Kim, 1969). The rapidity with which methyltransferases are activated makes these enzymes important in organisms undergoing major changes in metabolism and life cycles. Three distinct protein methylases have been identified and classified according to the type of amino substituent methylated. Protein methylase I (EC 2.1.1.23) is a cytosolic enzyme which methylates the guanidino group of arginine residues in proteins resulting in the formation of $\alpha-N$-methylarginine (Paik \& Kim, 1968). Protein methylase II (EC 2.1.1.24), also

Abbreviations: $S$-AdoMet, $S$-adenosyl-L-methionine; $S$-AdoHcy, $S$ adenosyl-L-homocysteine; DFMO, DL- $\alpha$-difluoromethylornithine. located in the cytosol, methylates protein carboxyl groups (Kim \& Paik, 1970). Protein methylase III (EC 2.1.1.43), located in the nucleus, methylates the $\varepsilon^{-}$ amino groups of lysine (Paik \& Kim, 1970).

Protein methylation reactions in kinetoplastids have been relatively unexplored. Because of the rapid morphological and biochemical changes in their life cycles, these organisms must be subject to rapid changes in activation of their genomes.

In this study, we examined the types of protein methylation reactions in bloodstream forms of African trypanosomes and determined their subcellular distribution. We examined the effects of the polyamine antagonist DL- $\alpha$-difluoromethylornithine (DFMO; Ornidyl) on protein methylation activities since this agent blocks growth of the parasite in vivo and causes numerous morphological and biochemical effects (Bacchi \& McCann, 1987). These include a dramatic (48-fold) increase in $S$-AdoMet which results in a 17 -fold increase in the methylation potential of bloodstream parasites (Yarlett \& Bacchi, 1988). The naturally occurring nucleoside antibiotic sinefungin, which is structurally similar to $S$-AdoHcy and $S$-AdoMet, has strong antimicrobial activity towards many protozoa, including the kinetoplastids (Bachrach et al., 1980; Nadler et al., 1982; Dube et al., 1983; Bacchi et al., 1987) and was a potent inhibitor of protein methylase II in Leishmania spp. (Avila \& Avila, 1987). Since sinefungin was active 


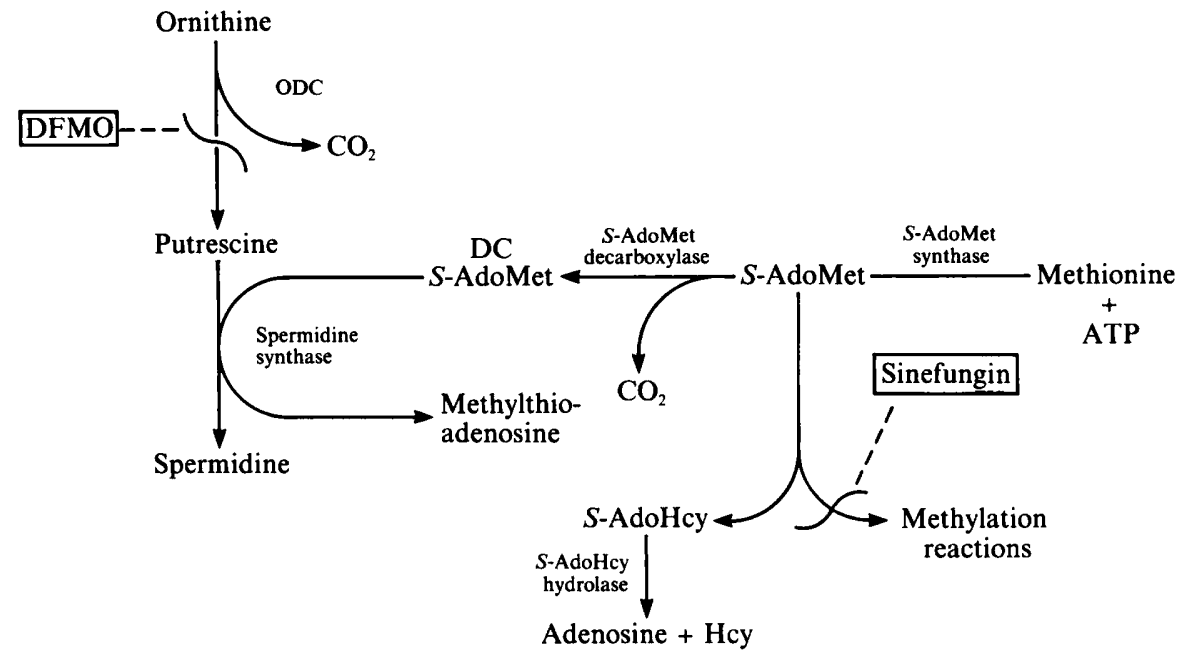

Fig. 1. Metabolism of $S$-adenosylmethionine. Inhibitors are indicated in boxes. Abbreviations: ODC, ornithine decarboxylase; DFMO, DL- $\alpha$-difluoromethylornithine; $S$-AdoMet, $S$-adenosylmethionine; $S$-AdoMet DC, $S$-AdoMet decarboxylase; DC $S$-AdoMet, decarboxylated $S$-AdoMet [(5-deoxy-5-adenosyl)(3-aminopropyl)methylsulphonium salt]; $S$-AdoHcy $S$-adenosylhomocysteine; Hcy, homocysteine.

against Trypanosoma brucei brucei in vivo (Bacchi et al., 1987) we examined the effect of this antibiotic upon trypanosome protein methylase II.

\section{Methods}

Parasites. Bloodstream trypomastigotes of T. b. brucei Lab 110 EATRO were obtained from infected rats $\left(10^{8} \mathrm{ml}^{-1}\right)$ and isolated by DEAE-cellulose chromatography after cardiac puncture (Lanham \& Godfrey, 1970). Rats with a $60 \mathrm{~h}$ infection were treated with $4 \%(\mathrm{w} / \mathrm{v})$ DFMO for $12 \mathrm{~h}$ or $36 \mathrm{~h}$ as described by Bacchi et al. (1983). Cells were washed in $70 \mathrm{~mm}$-potassium phosphate buffer containing $43 \mathrm{mM}$ sodium chloride, $1 \mathrm{~mm}$-EDTA and $1 \mathrm{~mm}$-dithiothreitol, pH 7.0, and broken by three cycles of freeze-thawing in a methanol/dry ice bath. Whole cells and membranes were removed by centrifugation at $2000 \mathrm{~g}$ for 5 min at $4{ }^{\circ} \mathrm{C}$ in a Sorvall RT6000 centrifuge (DuPont).

Cell fractionation. Cells were disrupted $\left(4^{\circ} \mathrm{C}\right)$ by grinding a cell paste consisting of two parts of Crystalon abrasive (Norton Co.) to one part cell pellet in osmotic buffer ( $250 \mathrm{~mm}$-sucrose containing $1 \mathrm{mM}$-EGTA and $3 \mathrm{~mm}$-imidazole. $\mathrm{HCl}, \mathrm{pH} \mathrm{7.0)}$. Most of the abrasive was removed by diluting the paste 30 -fold with osmotic buffer and centrifuging at $100 \mathrm{~g}$ for $8 \mathrm{~min}$. Differential fractionation of the homogenate was performed in a Sorvall RC-2B centrifuge equipped with an SS-34 rotor at $4{ }^{\circ} \mathrm{C}$ to give a nuclear fraction sedimenting after centrifugation at $1000 \mathrm{~g}$ for $10 \mathrm{~min}$, and large granule and cytosolic fractions, at $14500 \mathrm{~g}$ for $20 \mathrm{~min}$. Appropriate marker enzymes were run to check integrity and purity of fractions (Yarlett \& Bacchi, 1988).

Enzyme analysis. Trypanosome fractions from control and DFMOtreated rats were dialysed in $70 \mathrm{~mm}$-potassium phosphate buffer $(\mathrm{pH}$ $7 \cdot 0)$, as previously described $\left(4 \mathrm{~h}\right.$ at $4^{\circ} \mathrm{C}$; Yarlett \& Bacchi, 1988) to reduce levels of $S$-AdoMet and $S$-AdoHcy to those found in control cells. Activities of protein methylases were determined at $30^{\circ} \mathrm{C}$ by measuring the incorporation of $\left[{ }^{14} \mathrm{C}\right]$ methyl groups from $S$-Ado[methyl$\left.{ }^{14} \mathrm{C}\right] \mathrm{Met}\left(46 \mathrm{mCi} \mathrm{mmol}^{-1} ; 1702 \mathrm{MBq} \mathrm{mmol}^{-1}\right)$ into various protein acceptors.
Protein methylase I (EC 2.1.1.23) was determined in incubations containing $8.5 \mathrm{nmol} S$-Ado $\left[\right.$ methyl $\left.-{ }^{14} \mathrm{C}\right] \mathrm{Met}\left(7.3 \times 10^{5}\right.$ c.p.m. $)$ in $0.2 \mathrm{M}$ potassium phosphate buffer $\mathrm{pH} 7 \cdot 2,15 \mathrm{mg}$ histone II-A and 200 $300 \mu \mathrm{g}$ trypanosome protein in a total volume of $0.5 \mathrm{ml}$ (Paik \& Kim, 1968). Reactions were stopped after $30 \mathrm{~min}$ by addition of $0.5 \mathrm{ml} 30 \%$ (w/v) trichloroacetic acid. Protein was collected onto filter discs (Whatman GF/C, $2.4 \mathrm{~cm}$ ), resuspended in $10 \%$ trichloroacetic acid and heated to $90{ }^{\circ} \mathrm{C}$ for $20 \mathrm{~min}$ to remove nucleic acids. The precipitated protein was washed with hot $95 \%(\mathrm{v} / \mathrm{v})$ ethanol, followed by diethyl ether/ethanol/chloroform ( $2: 2: 1$, by vol.) and finally diethyl ether alone. The air-dried protein was dissolved in $0.5 \mathrm{M}$-potassium phosphate (pH 8.0) and left at room temperature for $2 \mathrm{~h}$ to hydrolyse the ester bond of carboxymethylated amino acids due to protein methylase II. The precipitated protein was resuspended in acetone, absorbed onto filter paper and radioactivity determined by scintillation counting.

Protein methylase II (EC 2.1.1.24) was measured in incubations containing $8.4 \mathrm{nmol} S$-Ado $\left[\right.$ methyl $\left.{ }^{-14} \mathrm{C}\right]$ Met $\left(7.3 \times 10^{5}\right.$ c.p.m. $)$ in $0.1 \mathrm{M}$-disodium phosphate and $0.03 \mathrm{M}$-citric acid, $\mathrm{pH} 6.0$, containing $6 \mathrm{~mol} 2$-mercaptoethanol, $15 \mathrm{mg}$ acceptor substrate protein and 200 $300 \mu \mathrm{g}$ trypanosome protein in a total volume of $0.5 \mathrm{ml}$ (Kim \& Paik, 1970). The reaction was terminated after 30 min with $30 \%$ trichloroacetic acid. Nucleic acids and phospholipids were removed as for protein methylase I, and the remaining protein was absorbed onto filters and counted. The identity of the methylated carboxyl group was checked by measuring the amount of $\left[\right.$ methyl $\left.-{ }^{14} \mathrm{C}\right]$ methanol formed after treatment of the reaction mixture with $1 \mathrm{ml} 0.5 \mathrm{M}$-sodium borate buffer (pH 11.0) and $6 \mathrm{ml}$ isoamyl alcohol/toluene $(4: 1, \mathrm{v} / \mathrm{v})$ (Diliberto \& Axelrod, 1974). The radioactivity in the organic phase was determined before and after overnight evaporation at room temperature (van Waarde \& van Hoof, 1985). The difference in ${ }^{14} \mathrm{CH}_{3}$ recovered in the two samples represents the volatile fraction, which is assumed to be methanol.

Protein methylase III (EC 2.1.1.43) was determined in incubations containing $0.1 \mathrm{M}$-Tris/HCl $\left(\mathrm{pH} \mathrm{9.0),} 8.4 \mathrm{nmol} S\right.$-Ado[methyl $\left({ }^{14} \mathrm{C}\right] \mathrm{Met}$ $\left(7.3 \times 10^{5}\right.$ c.p.m.), $15 \mathrm{mg}$ histone V-S and $200-300 \mu \mathrm{g}$ trypanosome protein in a final volume of $0.5 \mathrm{ml}$ (Paik \& $\mathrm{Kim}, 1970$ ). The reaction was stopped after 30 min with $30 \%$ trichloroacetic acid and treated as described for protein methylase I to remove nucleic acids and 
phospholipids. The precipitated protein was resuspended in $0.2 \mathrm{M}-$ $\mathrm{NaOH}$ at $100^{\circ} \mathrm{C}$ for $2 \mathrm{~h}$ to remove methylarginine and carboxylmethylated amino acids, neutralized with $0.5 \mathrm{M}-\mathrm{HCl}$, absorbed onto filter paper and the radioactivity measured.

Protein methylase activities are expressed as pmol ${ }^{14} \mathrm{CH}_{3}$ - incorporated $\min ^{-1}$ (mg trypanosome protein) $)^{-1}$. S-AdoMet synthase (methionine adenosyltransferase; EC 2.5.1.6) and $S$-AdoHcy hydrolase (EC 3.3.1.1) were determined as described previously (Yarlett \& Bacchi, 1988).

Partial purification of protein methylase $I$. Approximately $900 \mathrm{mg}$ of $T$. b. brucei crude homogenate was obtained from a freeze-thawed cell pellet after centrifugation at $2000 \mathrm{~g}$ for $70 \mathrm{~min}$ at $4{ }^{\circ} \mathrm{C}$. The homogenate was treated with $25 \%$ saturation $\left(\mathrm{NH}_{4}\right)_{2} \mathrm{SO}_{4}$ at $4{ }^{\circ} \mathrm{C}$ for $30 \mathrm{~min}$. The supernatant obtained by centrifugation was brought up to $50 \%$ saturation $\left(\mathrm{NH}_{4}\right)_{2} \mathrm{SO}_{4}$ by gradual addition with gentle stirring. After centrifugation, the pellet was suspended in $3 \mathrm{ml} 70 \mathrm{~mm}$-potassium phosphate buffer containing $4.3 \mathrm{~mm}-\mathrm{NaCl}$ and $300 \mathrm{~mm}$-glucose. An equal volume of calcium phosphate gel $\left(16.5 \mathrm{mg} \mathrm{ml}^{-1}\right)$ was added to the above suspension, the gel was washed with $40 \mathrm{ml}$ of water and the protein eluted with $2 \times 6 \mathrm{ml}$ portions of $0.2 \mathrm{M}$-potassium phosphate buffer, $\mathrm{pH} 7 \cdot 2$. The resulting eluate was concentrated to $2 \mathrm{ml}$ by sucrose dialysis. Protein was estimated by the Lowry method.

Chemicals. $S$-Ado $\left[\right.$ methyl $\left.-{ }^{14} \mathrm{C}\right]$ Met was obtained from E. I. Dupont (New England Nuclear Products). Sinefungin, histone II-A (undefined from calf thymus), III-S (lysine-rich), V-S (lysine-rich subgroup $f_{1}$ ), VIII-S (arginine-rich subgroup $f_{3}$ ), bovine serum albumin and $\gamma$ globulin were obtained from Sigma. Gelatin was from Difco. Details of the aspartate and glutamate content of histone VIII-S were provided by Sigma.

\section{Results}

\section{Enzyme studies}

Protein methylases I (arginine), II (aspartate and glutamate), and III (lysine) were detected in homogenates of T. b. brucei (Table 1). Protein methylase I appeared to have the highest activity, while protein methylases II and III had similar but lower activities in fractionated homogenates. Subcellular fractionation of homogenates revealed that protein methylases I and II were predominantly cytosolic, whereas protein methylase III was confined to the nuclear fraction. As detailed below, protein methylase II activity increased significantly during DFMO treatment of trypanosomes and for this reason it was studied in detail.

In terms of substrate specificity, protein methylase II had highest activity with histone type VIII-S (argininerich subgroup $\mathrm{f}_{3}$ ) as exogenous substrate (Table 2), and had a broad $\mathrm{pH}$ optimum which peaked at 6.0 in citrate/phosphate buffer (range 4-14). Under the assay conditions described, the incorporation of ${ }^{14} \mathrm{CH}_{3}$ - into substrate protein by protein methylase II was linear up to 30 min (not shown). The identity of the methyl group was confirmed by alkali treatment of the acidified pellet. The counts present in the pellet were taken to be $100 \%$, and this was compared to counts present after overnight incubation of the pellet with $\mathrm{pH} 11.0$ borate (aqueous phase), and extraction with an organic phase of $4: 1(\mathrm{v} / \mathrm{v})$ isoamyl alcohol/toluene (Table 3 ). The organic and aqueous fractions were dried at $30^{\circ} \mathrm{C}$ under $\mathrm{N}_{2}$, and the differences in counts recovered were assumed to be the result of the evaporation of methanol formed from the alkaline esterification of the carboxyl group (Diliberto \& Axelrod, 1974). The temperature used to evaporate the methanol formed by borate treatment is critical to the correct identification of the volatilized product since high temperature causes degradation of methylmethionine (van Waarde \& van Hoof, 1985). This treatment revealed that $73 \%$ of the incorporated label was present as the alkali-labile carboxyl form when the assay was

Table 1. Subcellular distribution of protein methylases

$T$. $b$. brucei bloodstream forms were purified and homogenates made as described in Methods. The nuclear fraction was sedimented at $1000 \mathrm{~g}$ for $10 \mathrm{~min}$, the large particle fraction sedimented at $14500 \mathrm{~g}$ for $20 \mathrm{~min}$, and the non-sedimentable material was termed the cytosolic fraction. The amount of protein used in each assay, with the percentage recovered in parenthesis were: homogenates $390 \mu \mathrm{g}$; nuclear $210 \mu \mathrm{g}$ $(40.3 \%)$; large particle, $120 \mu \mathrm{g}(15.4 \%)$, cytosolic, $60 \mu \mathrm{g}(38.5 \%)$. Activities of protein methylases were determined using the following substrates as methyl acceptors: $15 \mathrm{mg}$ histone II-A for protein methylase I, $15 \mathrm{mg}$ histone VIII-S for protein methylase II, and $15 \mathrm{mg}$ histone V-S for protein methylase III. Results are presented as the mean of duplicate experiments \pm population standard deviation, with percentage activity recovered in each fraction in parenthesis.

\begin{tabular}{|c|c|c|c|c|}
\hline & \multicolumn{4}{|c|}{ Activity [pmol $\min ^{-1}$ (mg protein) $\left.)^{-1}\right]$} \\
\hline $\begin{array}{l}\text { Protein } \\
\text { methylase }\end{array}$ & Homogenate & Nuclear & $\begin{array}{c}\text { Large } \\
\text { particle }\end{array}$ & Cytosolic \\
\hline $\begin{array}{l}\text { I } \\
\text { II } \\
\text { III }\end{array}$ & $\begin{array}{l}7.2 \pm 0.7 \\
4 \cdot 1 \pm 1.0 \\
3.5 \pm 0.4\end{array}$ & $\begin{array}{l}0.10 \pm 0.01(0.6) \\
0.07 \pm 0.04(0.7) \\
7.70 \pm 0.80(89)\end{array}$ & $\begin{array}{l}5.9 \pm 0.90(12.5) \\
0.3 \pm 0.18(1 \cdot 1) \\
1.0 \pm 0.20(4 \cdot 4)\end{array}$ & $\begin{array}{c}20 \cdot 3 \pm 1 \cdot 2(108) \\
8 \cdot 3 \pm 1 \cdot 2(79) \\
0 \cdot 4 \pm 0 \cdot 2(4 \cdot 4)\end{array}$ \\
\hline
\end{tabular}


Table 2. Substrate specificities for protein methylase II

Histone II-A consists of a mixed histone fraction, histone III-S is a lysinerich fraction, Histone V-S has a lysine-rich subgroup $f_{1}$, histone VIII-S has an arginine-rich subgroup $f_{3}$ (Sigma designations). $K_{m}$ and $V$ (saturation velocity) values were determined from Lineweaver-Burk plots using a substrate range of $2-30 \mathrm{mg} \mathrm{ml}^{-1} . V$ is expressed as pmol incorporated methyl group $\min ^{-1}$ (mg protein) $)^{-1}$. Percentage of control is the activity of the enzyme in the presence of the substrate compared to that in controls lacking exogenous protein acceptor substrate. The enzyme assays contained 200$300 \mu \mathrm{g}$ trypanosome protein. The results are presented as the arithmetic mean \pm population standard deviation of the number of experiments shown in parenthesis.

\begin{tabular}{lccc}
\hline \hline Substrate & $V$ & $K_{\mathrm{m}}\left(\mathrm{mg} \mathrm{m}^{-1}\right)$ & $\begin{array}{c}\text { Percentage of } \\
\text { control }\end{array}$ \\
\hline Histone II-A & $2 \cdot 75 \pm 0.85$ & $3 \cdot 2 \pm 1 \cdot 40$ & $1101 \pm 208(3)$ \\
Histone III-S & $0.93 \pm 0.31$ & $2 \cdot 0 \pm 0.44$ & $661 \pm 37(3)$ \\
Histone V-S & $0 \cdot 26 \pm 0.08$ & $8 \cdot 0 \pm 1 \cdot 20$ & $288 \pm 31(3)$ \\
Histone VIII-S & $3 \cdot 6 \pm 1 \cdot 20$ & $26 \cdot 2 \pm 2 \cdot 00$ & $2772 \pm 209(5)$ \\
Gelatin & $0 \cdot 36 \pm 0$ & $1 \cdot 4 \pm 0 \cdot 22$ & $366 \pm 19(2)$ \\
$\gamma$-Globulin & $0 \cdot 70 \pm 0.01$ & $2 \cdot 6 \pm 0.40$ & $479 \pm 90(2)$ \\
Bovine serum albumin & $0.45 \pm 0.17$ & $4 \cdot 0 \pm 1 \cdot 60$ & $1108 \pm 304(2)$ \\
\hline \hline
\end{tabular}

Table 3. Effect of alkali treatment, organic extraction and evaporation at $23^{\circ} \mathrm{C}$ on the incorporated ${ }^{14} \mathrm{CH}_{3}$ -

\begin{tabular}{lcr}
\hline \hline & \multicolumn{2}{c}{$\begin{array}{c}\text { Percentage of starting } \\
\text { material }\end{array}$} \\
\cline { 2 - 3 } & \multicolumn{2}{c}{ Assay incubated at: } \\
& $\mathrm{pH} \mathrm{6.0}$ & $\mathrm{pH} \mathrm{9.0}$ \\
\hline Pellet prior to extraction & 100 & 100 \\
Pellet after borate incubation & 24 & 68 \\
Organic phase & 64 & 19 \\
Organic phase evaporated & 3 & 2 \\
Aqueous phase & 0 & 4 \\
Aqueous phase evaporated & 0 & 7 \\
Volatile fraction & 73 & 26 \\
\hline \hline
\end{tabular}

incubated at $\mathrm{pH} 6 \cdot 0$, as compared to only $26 \%$ when the assay was performed at $\mathrm{pH} 9 \cdot 0$. The methylated product was stable at acid $\mathrm{pH}(15 \%$ TCA) for up to $1 \mathrm{~h}$.

The activities of the three transmethylases, and of $S$ AdoMet synthase and $S$-AdoHcy hydrolase were determined in DFMO-treated and control cells since in previous studies we had shown a 48 -fold increase in $S$ AdoMet levels in DFMO-treated trypanosomes and a rise in the cell methylation index from a normal of 6.5 to 114 (Yarlett \& Bacchi, 1988). S-AdoMet synthase and $S$ AdoHcy hydrolase activities increased to $227 \%$ and $366 \%$, respectively, that of control cells after $36 \mathrm{~h}$ of DFMO treatment (Table 4). Protein methylase activities were determined in the same extracts which had been dialysed to remove excess $S$-AdoMet and $S$-AdoHcy. The activity of protein methylase I under these condi-
Table 4. Effect of DFMO $(4 \%$ in drinking water $)$ on activities of methylation enzymes

Enzyme activities were determined after $12 \mathrm{~h}$ and $36 \mathrm{~h}$ treatment of rats with a $60 \mathrm{~h}$ bloodstream infection. Activities of protein methylases were determined using optimal amounts of histone substrates described in Table 1 , and results are expressed as percentages of control values after correction for protein concentration (arithmetic means of two determinations, \pm population standard deviations). The assays contained $320 \mu \mathrm{g}$ of trypanosome homogenate protein. Control values for protein methylases are given in Table 1 ; values for $S$-AdoMet synthase and $S$-AdoHcy hydrolase were 100 and $87 \mathrm{pmol}^{\mathrm{min}^{-1}}$ (mg protein) $)^{-1}$, respectively.

\begin{tabular}{lcc}
\hline \hline & \multicolumn{2}{c}{$\begin{array}{c}\text { Percentage of control } \\
\text { activity }\end{array}$} \\
\cline { 2 - 3 } \multicolumn{1}{c}{ Enzyme } & $12 \mathrm{~h}$ & $36 \mathrm{~h}$ \\
\hline Protein methylase I & $46 \pm 6$ & $41 \pm 3$ \\
Protein methylase II & $267 \pm 17$ & $606 \pm 26$ \\
Protein methylase III & $42 \pm 4$ & $117 \pm 9$ \\
$S$-AdoMet synthase & $170 \pm 18$ & $227 \pm 10$ \\
$S$-AdoHcy hydrolase & $354 \pm 31$ & $366 \pm 12$ \\
\hline \hline
\end{tabular}

tions was about $60 \%$ lower than in dialysed controls. Protein methylase II activity increased dramatically in extracts of DFMO-treated trypanosomes, approaching a six-fold greater activity after $36 \mathrm{~h}$ compared to dialysed controls (Table 4). Protein methylase III appeared initially to decrease to about $40 \%$ of control activity after $12 \mathrm{~h}$ of DFMO exposure; however the activity then increased to about the normal control level after $36 \mathrm{~h}$ (Table 4). 

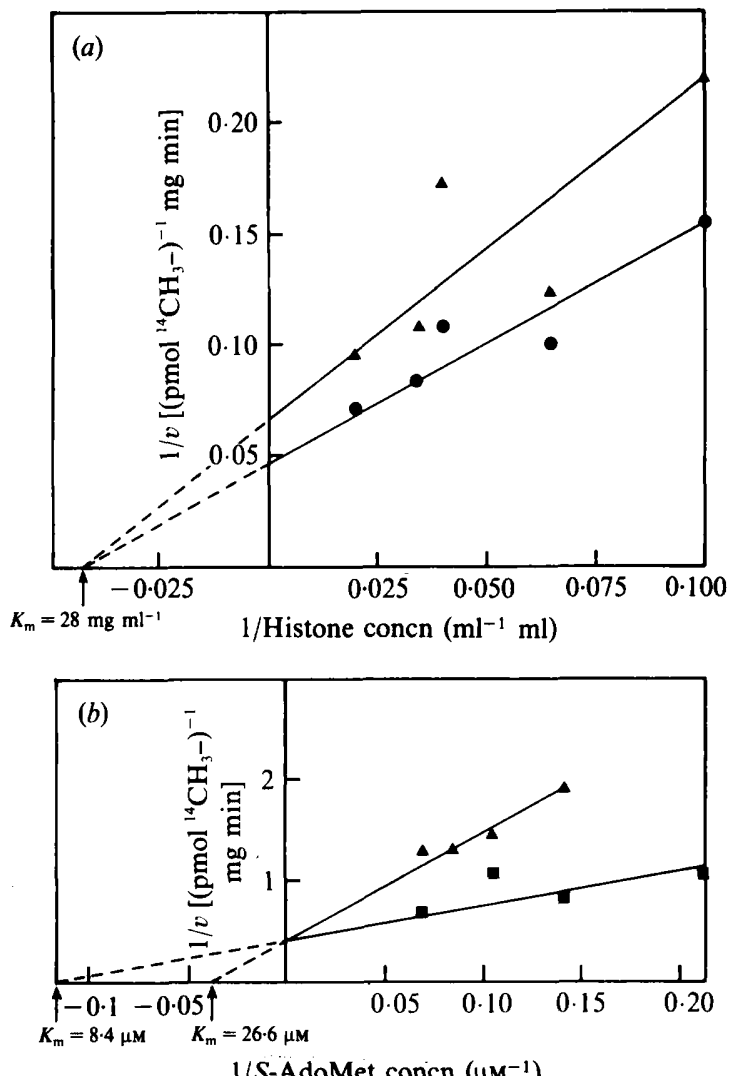

1/S-AdoMet concn $\left(\mu \mathrm{M}^{-1}\right)$

Fig. 2. Lineweaver-Burk kinetics of protein methylase II. (a) Substrate affinity for histone VIII-S. The reaction mixture contained $16.8 \mu \mathrm{M}-S$ Ado[ $\left[\right.$ methyl $\left.{ }^{-14} \mathrm{C}\right] \mathrm{Met}$ and $25 \mu \mathrm{g}$ partially purified protein methylase II. The histone VIII-S concentration was varied from 10 to $40 \mathrm{mg} \mathrm{ml}^{-1}$ in the absence ( $)$ and presence $(\boldsymbol{A})$ of $1 \mu \mathrm{M}$-sinefungin. (b) Substrate affinity for $S$-AdoMet. The reaction mixture contained $30 \mathrm{mg} \mathrm{m}^{-1}$ histone VIII-S and $240 \mu \mathrm{g}$ trypanosome homogenate protein. The $S$ $\mathrm{Ado}\left[\right.$ methyl $\left({ }^{14} \mathrm{C}\right] \mathrm{Met}$ was varied from 4 to $20 \mu \mathrm{M}$ in the absence $(\boldsymbol{\square})$ and presence $(\boldsymbol{\Lambda})$ of sinefungin.

\section{Partial purification of protein methylase II}

Partial purification of protein methylase II was attempted with the aim of removing endogenous substrate from the preparation. The purification procedure (Paik \& Kim, 1968; Kim \& Paik, 1970) used $\left(\mathrm{NH}_{4}\right)_{2} \mathrm{SO}_{4}$ precipitation and $\mathrm{Ca}\left(\mathrm{PO}_{4}\right)_{2}$ gel binding, which resulted in a five-fold increase in specific activity [to $16.7 \mathrm{pmol}$ $\min ^{-1}$ (mg protein $)^{-1}$ ] and a yield of $28 \%$ of the starting material. SDS-PAGE of the partially purified protein fraction revealed a relative increase $(8-10$-fold) in intensity of the band at $55 \mathrm{kDa}$ (not shown). While other bands remained, only this one band appeared to increase, all other bands decreasing in intensity. More importantly, however, kinetic studies revealed no endogenous enzyme activity in the absence of histone VIII-S, and these preparations had no $S$-AdoMet synthase or $S$ AdoHcy hydrolase activities. Lineweaver-Burk determinations using the partially purified protein methylase II from $T$. $b$. brucei revealed that the enzyme had an apparent affinity $\left(K_{\mathrm{m}}\right)$ for histone VIII-S of $28 \mathrm{mg} \mathrm{ml}^{-1}$, which is similar to the value determined for the unpurified enzyme (Table 2). The $K_{\mathrm{m}}$ for histone VIII-S corresponds to $11.4 \mathrm{~mm}$-aspartyl and $18.4 \mathrm{~mm}$-glutamyl residues, assuming that all the carboxyl amino acids in histone VIII-S are methylated (Fig. $2 a$ ). An apparent $K_{\mathrm{m}}$ for $S$-AdoMet of $8.4 \mu \mathrm{M}$ was determined for the unpurified enzyme (Fig. $2 b$ ).

\section{Inhibitor studies}

The nucleoside antibiotic sinefungin was an effective inhibitor of protein methylase II from $T . b$. brucei, with an apparent $K_{\mathrm{i}}$ (concentration causing $50 \%$ inhibition of activity) for the crude enzyme of $1.6 \pm 0.6 \mu \mathrm{M}$ (range 0.5 $10 \mu \mathrm{M}$ ) for triplicate determinations (not shown). The kinetics of protein methylase II inhibition by sinefungin were investigated by measuring the enzyme activity with varying concentrations of histone in the absence and presence of $1 \mu \mathrm{M}$-sinefungin. Lineweaver-Burk analysis indicated non-competitive inhibition of histone methylation (Fig. $2 a$ ). Repeating the experiment with varying $S$ AdoMet concentrations indicated competitive inhibition of protein methylase II activity as determined by Lineweaver-Burk analysis (Fig. $2 b$ ). $S$-AdoHcy was less effective as an inhibitor of the enzyme from $T$. b. brucei, with an apparent $K_{\mathrm{i}}$ of $12.9 \pm 0.05 \mu \mathrm{M}$ (range 0.5-25 $\mu \mathrm{M}$ ) for triplicate determinations (not shown).

\section{Discussion}

$S$-AdoMet is formed from methionine and ATP by $S$ AdoMet synthase and has a pivotal role in polyamine biosynthesis as amino propyl group donor to putrescine and spermidine, and in methylation reactions as methyl donor to proteins, lipids and nucleic acids (Fig. 1). It was previously demonstrated that treatment of $T . b$. brucei with the polyamine antagonist DFMO elevates levels of both decarboxylated $S$-AdoMet and $S$-AdoMet (Fairlamb et al., 1987; Yarlett \& Bacchi, 1988), resulting in a 17.5-fold increase in the methylation index of the cell and with it the likelihood of aberrations in activities of methyltransferase enzymes (Yarlett \& Bacchi, 1988). In the present study both $S$-AdoMet synthase and $S$ AdoHcy hydrolase activities increased in DFMO-treated bloodstream trypanosomes. After $36 \mathrm{~h}$ of treatment the synthase was elevated more than twofold and the hydrolase had increased more than threefold (Table 4). Both of these enzymes are critical to cellular methylation: the synthase for the provision of methyl substrate groups and the hydrolase in the removal of $S$-AdoHcy, a potent inhibitor of most methyltransferase reactions. 
Three distinct protein methylases, designated I, II and III, according to the definition of Paik et al. (1972) were detected in extracts of $T . b$. brucei. Protein methylase II acts on the carboxyl groups of aspartate and glutamate, resulting in the formation of a carboxyl methyl ester. The preferred substrate for the parasite protein methylase II was histone VIII-S, which possesses an arginine-rich subgroup $f_{3}$, and the nature of the methylated product was confirmed by alkaline hydrolysis and evaporation (Diliberto \& Axelrod, 1974; van Waarde \& van Hoof, 1985). The enzyme was initially found to have a broad pH optimum, but based upon alkali lability of the carboxyl methyl ester, we determined that the parasite enzyme has a narrow $\mathrm{pH}$ range of $5 \cdot 5-6 \cdot 0$, which is similar to that determined for the mammalian enzyme (Kim \& Paik, 1970; Diliberto \& Axelrod, 1974; Paik et al., 1988), but different from the plant enzyme, which has a $\mathrm{pH}$ optimum of 7.0 (Trivedi et al., 1982).

The reduction in activities of protein methylases I and III after $12 \mathrm{~h}$ exposure to DFMO was consistently observed. This may be due to negative control by $S$ AdoMet, or possibly to the rapid increase in $S$-AdoHcy (Yarlett \& Bacchi, 1988), a product of the methylase reaction. That protein methylase III recovers in cells treated with DFMO for $36 \mathrm{~h}$, even though $S$-AdoMet continues to increase, suggests that the observed reduction in the activity of the cells treated for $12 \mathrm{~h}$ is not due to elevated $S$-AdoMet, but may be due to initial perturbations of $S$-AdoHcy prior to increase in hydrolase activity. In contrast, the activity of protein methylase II consistently increased in trypanosomes exposed to DFMO. The differential activities of these enzymes when trypanosomes are exposed to DFMO suggests that these enzymes are under tight control by either the substrate, or the product, or the substrate/product ratio, a significant property for any control mechanism which might participate in the rapid changes of transformation which accompany DFMO administration (Giffin et al., 1986; Giffin \& McCann, 1989).

The increased activity of protein methylase II may be indicative of hypermethylation of protein (histone, cytoskeletal, calcium-binding, etc.) in T. b. brucei, which may have profound effects. Duschak \& Cazzulo (1990) have shown that total histones from the trypanosome Crithidia fasciculata are similar in content of acidic amino acids (aspartate and glutamate) to calf thymus histone. In addition these authors show that band 5 of the $\mathrm{H}_{1}$ histone fraction is unusually rich in acidic amino acids $(27.1 \mathrm{~mol} \%$ compared to $9.5 \mathrm{~mol} \%$ from calf thymus $\mathrm{H}_{1}$ histone fraction: Dushak \& Cazzulo, 1990). This unusual feature may play a functional role in control of histone by carboxyl methylation. Several studies suggest that histone methylation may be involved in the condensation of euchromatin to heterochromatin prior to mitosis (Tidwell et al., 1968; Shepherd et al., 1971; Paik et al., 1972). Methyl substitution on the amino group influences the pK value of histone (Fieser \& Fieser, 1963), and since histone exists in situ in conjunction with DNA or RNA, modification of histone molecules by methylation would be expected to affect gene expression. The parasite protein methylase II was found to be a cytosolic enzyme, and since histone is synthesized in the cytoplasm in mammalian cells (Robbins \& Borun, 1967), methylation may play an important role in controlling the rate of transport of this protein through the nuclear membrane (Paik et al., 1972). The natural substrate for the enzyme in T.b. brucei is not known. Histone VIII-S proved to be the best substrate of those tested but it is possible that the natural substrate is not a histone protein. It is also likely that several proteins are methylated by the enzyme and that perturbations resulting from hypermethylation result in uncontrolled methylation at more than one site. It is clear from the literature that post translational control of proteins by carboxyl methylation does play an important role in the modification of proteins involved in secretion, chemotaxis and cytoskeletal structure during differentiation, and the activity of protein methylase II increases in rapidly dividing and differentiating cells (Zukerman et al., 1982; Kloog et al., 1983; Paik et al., 1988; Haklai \& Kloog, 1990).

The production of hypermethylated end-products due to an elevated methylation index and increased activity of protein methylase II is one possible mechanism for the major morphological and biochemical changes observed in T. b. brucei cells undergoing DFMO treatment (Bacchi et al., 1983; de Gee et al., 1984; Giffin et al., 1986; Giffin $\&$ McCann, 1989). These events feature the development of stumpy forms from slender blood forms and activation of the quiescent mitochondrial genome to produce cytochromes and other respiratory proteins (Giffin \& McCann, 1989; Bienen et al., 1983; Feagin et al., 1986). The involvement of methylation in these events is further bolstered by the recent studies of Penketh et al. (1990), who studied the effects of known methylating agents on trypanosome infections. These agents were therapeutically active in extending the lifespan and/or curing model infections and at low doses were able to synchronously transform slender blood forms to stumpy forms.

Sinefungin, a naturally produced antibiotic and structural analogue of $S$-AdoMet and $S$-AdoHcy, is a potent growth inhibitor of Leishmania spp. and Trypanosoma spp. (Bachrach et al., 1980; Dube et al., 1983; Paolantonacci et al., 1985; Avila \& Avila, 1987; Bacchi et al. 1987; Nolan, 1987). In Leishmania, growth inhibition in vitro was completely reversible by concurrent addition of exogenous $S$-AdoMet (Paolantonacci $e t$ 
al., 1987; Nolan, 1987). Although sinefungin, due to its structural similarity to $S$-AdoHcy, has been shown to be a strong inhibitor of methyltransferase activity in mammalian cells (Fuller \& Nagarajan, 1978), its target in kinetoplastids has been elusive. Sinefungin inhibits DNA synthesis in intact Leishmania (Blanchard et al., 1986), by a mechanism that is not related to uptake or phosphorylation of thymidine (Paolantonacci et al., 1987). The compound is weakly inhibitory to protein methylases I and III from Leishmania (Paolantonacci et al., 1986), but highly inhibitory to protein methylase II ( $K_{\mathrm{i}} 2 \mu \mathrm{M}$ : Avila \& Avila, 1987). T. b. brucei protein methylase II was found to be sensitive to sinefungin inhibition with an apparent $K_{\mathrm{i}}$ of $1.6 \mu \mathrm{M}$. There appear to be multiple binding sites on the enzyme, for which sinefungin is a competitive inhibitor of the $S$-AdoMet binding site and a non-competitive inhibitor of the histone binding site. The strain of T. b. brucei used in the present study was susceptible to sinefungin in vivo in mouse infections (Bacchi et al., 1987). We intend to examine protein methylase II in strains of parasites refractory to sinefungin in vivo to determine whether, as in Leishmania, the enzyme from these sources also has diminished sensitivity to the antibiotic.

The $T$. b. brucei protein methylase II was inhibited by $S$-AdoHcy with an apparent $K_{\mathrm{i}}$ of $12.9 \mu \mathrm{M}$, which is higher than that reported for the enzymes of Leishmania mexicana or L. braziliensis strains (Avila \& Avila, 1987), which have apparent $K_{\mathrm{i}}$ values in the range 0.9-1.6 $\mu \mathrm{M}$. In contrast to other organisms which have been examined (Avila \& Avila, 1987; Haklai \& Kloog, 1987; Paik et al., 1988) the trypanosome protein methylase is sixfold more sensitive to sinefungin than the natural regulator $S$-AdoHcy.

The aim of this study was to characterize protein methylases in $T . b$. brucei. It is likely that nucleic acid methylases and lipid methylases are also present and would be affected by the altered methylation index in DFMO-treated cells. The presence of methylated DNA has been described in Trypanosoma cruzi (Rojas \& Galanti, 1990), although no methylcytosine residues were detected in African trypanosome DNA (Bernards et al., 1984; Pays et al., 1984). However, the African trypanosomes do methylate RNA: in particular the common leader sequence of the mRNA has a 7methylguanosine $\left(\mathrm{m}^{7} \mathrm{G}\right)$ cap (Perry et al., 1987). The role of DNA and RNA methylations in T.b. brucei and their modulation by DFMO is presently being explored in our laboratory.

In summary, we have demonstrated the presence of three distinct protein-methylating activities in $T$. $b$. brucei, and found that in DFMO-treated cells, the levels of protein methylase II increased significantly. Elevation of the methylating potential of the trypanosome upon
DFMO treatment and resultant post-translational modifications of protein may be one effect in a cascade of events which result in the observed morphological changes and trypanocidal efficacy of DFMO.

Note added in proof. Since this paper went to press, Byers, T. L., Bush, T. L., McCann, P. P. \& Bitonti, A. J. (1991) Biochemical Journal (in the Press) have demonstrated that a greater correlation exists between the efficacy of several polyamine antagonists and the increase of intracellular AdoMet pools than depletion of polyamine pools.

The authors thank Dr P. P. McCann of the Marion Merrell Dow Research Institute for supplies of DFMO and Joanne Garofalo, Angela Santana and Karen Alecia for technical assistance. This work was funded by NIH grant AI 17340, and a grant from the UNDP/World Bank/World Health Organization Special Programme for Training in Tropical Disease (WHO 890064).

\section{References}

Avila, J. L. \& Avila, A. (1987). Correlation of sinefungin susceptibility and drug-affinity for protein carboxymethyltransferase activity in American Leishmania species. Molecular and Biochemical Parasitology 26, 69-76.

BaCCHI, C. J. \& McCanN, P. P. (1987). Parasitic protozoa and polyamines. In Inhibition of Polyamine Metabolism pp. 317-344. Edited by P. P. McCann, A. E. Pegg \& A. Sjoerdsma. New York: Academic Press.

Bacchi, C. J., Garofalo, J., Mockenhaupt, D., McCann, P. P., Diekema, K. A., PegG, A. E., Nathan, H. C., Mullaney, E. A., Chunosoff, L. T., SJoerdsma, A. \& Hutner, S. H. (1983). In vivo effects of DL- $\alpha$-difluoromethylornithine on the metabolism and morphology of Trypanosoma brucei brucei. Molecular and Biochemical Parasitology 7, 209-225.

Bacchi, C. J., Berens, R. L., Nathan, H. C., Klein, R. S., Elegbe, I. A., Rao, K. V. B., McCanN, P. P. \& MarR, J. J. (1987). Synergism between 9-deazainosine and $\mathrm{DL}-\alpha$-difluoromethylornithine in treatment of experimental African trypanosomiasis. Antimicrobial Agents and Chemotherapy 31, 1406-1413.

Bachrach, U., Schnur, L. F., El-On, J., Greenblatt, C. L., Pearlman, E., Robert-Gero, M. \& Lederer, E. (1980). Inhibitory action of sinefungin and SIBA ( $5^{\prime}$-deoxy- $5^{\prime}-S$-isobutylthioadenosine) on the growth of promastigotes and amastigotes of different species of Leishmania. FEBS Letters 121, 287-291.

Bernards, A., van Harten-Loosbroek, N. \& Borst, P. (1984). Modification of telomeric DNA in Trypanosoma brucei; a role in antigenic variation? Nucleic Acids Research 12, 4153-4170.

Bienen, E. J., Hill, G. C. \& SHIN, K. O. (1983). Elaboration of mitochondrial function during Trypanosoma brucei differentiation. Molecular and Biochemical Parasitology 7, 75-86.

Blanchard, P., Dodic, N., Fourrey, J. L., Geze, M., Lawrence, F., Malina, H., Paolantonacci, P., Vedel, M., Tempete, C., RobertGero, M. \& LeDERER, E. (1986). Sinefungin and derivatives: synthesis, biosynthesis and molecular target studies in Leishmania. In Biological Methylation and Drug Design, pp. 435-446. Edited by R. T. Borchardt, C. R. Creveling \& P. M. Ueland. Clifton: The Humana Press.

Diliberto, E. J. \& AXelrod, J. (1974). Characterization and substrate specificity of a protein carboxymethylase in the pituitary gland. Proceedings of the National Academy of Sciences of the United States of America 71, 1701-1704.

Dube, D. K., Mpimbaza, G., Allison, A. C., Lederer, E. \& Rovis, L. (1983). Antitrypanosomal activity of sinefungin. American Journal of Tropical Medicine and Hygiene 32, 31-33. 
Duschak, V. G. \& Cazzulo, J. J. (1990). The histones of the insect trypanosomatid, Crithidia fasciculata. Biochimica et Biophysica Acta 1040, 159-166.

Fairlamb, A., Henderson, G. B., Bacchi, C. J. \& Cerami, A. (1987). In vivo effects of difluoromethylornithine on trypanothione and polyamine levels in bloodstream forms of Trypanosoma brucei. Molecular and Biochemical Parasitology 24, 185-192.

Feagin, J. E., Jasmer, D. P. \& Stuart, K. (1986). Differential mitochondrial gene expression between slender and stumpy bloodforms of Trypanosoma brucei. Molecular and Biochemical Parasitology 20, 207-214.

Fieser, L. F. \& Fieser, M. (1963). Advanced Organic Chemistry. New York: Reinhold

Fuller, R. W. \& Nagarajan, R. (1978). Inhibition of methyltransferases by some new analogs of $S$-adenosylhomocysteine. Biochemical Pharmacology 27, 1981-1983.

De Gee, A. L. W., Carsten, P. H. B., McCann, P. P. \& Mansfield, J. M. (1984). Morphological changes in Trypanosoma brucei rhodesiense following inhibition of polyamine biosynthesis in vivo. Tissue and Cell 16, 731-738.

Giffin, B. F. \& McCANN, P. P. (1989). Physiological activation of the mitochondrion and the transformation capacity of DFMO-induced intermediate and short stumpy bloodstream form trypanosomes. American Journal of Tropical Medicine and Hygiene 40, 487-493.

Giffin, B. F., McCanN, P. P., Bitonti, A. J. \& BaCchi, C. J. (1986). Polyamine depletion following exposure to $\mathrm{DL}-\alpha$-difluoromethylornithine both in vivo and in vitro initiates morphological alterations and mitochondrial activation in a monomorphic strain of Trypanosoma brucei brucei. Journal of Protozoology 33, 238-243.

HAKLAI, R. \& KLOOG, Y. (1990). Carboxyl methylation of 21-23 kDa membrane proteins in intact neuroblastoma cells is increased with differentiation. FEBS Letters 259, 233-236.

KIM, S. (1977). Enzymatic esterification of proteins. In The Biochemistry of Adenosylmethionine, pp. 415-434. Edited by F. Salvatore, E. Borek, V. Zappia, H. G . Williams-Ashman \& F. Schlenk. New York: Columbia University Press.

KIM, S. \& PAIK, W. K. (1970). Purification and properties of protein methylase II. Journal of Biological Chemistry 245, 1806-1813.

KLOOG, Y., AXELROD, J. \& SPECTOR, I. (1983). Protein carboxylmethylation increases in parallel with differentiation of neuroblastoma cells. Journal of Neurochemistry 40, 522-529.

LANHAM, S. M. \& Godfrey, D. G. (1970). Isolation of salivarian trypanosomes from man and other animals using DEAE cellulose. Experimental Parasitology 28, 521-523.

NadLER, J. P., Lederer, E., WitTNer, M., Baum, S. G. \& TANowitz, H. B. (1982). The effect of adenosine analogues on the in vitro growth of Trypanosoma cruzi. Transactions of the Royal Society of Tropical Medicine and Hygiene 76, 285-287.

NoLAN, L. (1987). Molecular target of the antileishmanial action of sinefungin. Antimicrobial Agents and Chemotherapy 31, 1542-1548.

PaIK, W. K. \& KIM, S. (1968). Protein methylase I. Purification and properties of the enzyme. Journal of Biological Chemistry 243, 21082114.

PaIK, W. K. \& KIM, S. (1969). Enzymatic methylation of histones. Archives of Biochemistry and Biophysics 134, 632-637.

PAIK, W. K. \& KIM, S. (1970). Solubilization and partial purification of protein methylase III from calf thymus nuclei. Journal of Biological Chemistry 245, 6010-6015.

PaIK, W. K. \& KIM, S. (1980). Protein Methylation. Chichester: John Wiley.
PAIK, W. K., LeE, H. W. \& Morris, H. P. (1972). Protein methylases in hepatomas. Cancer Research 32, 37-40.

PaIK, M. K., Hwang, B. D. AND LIM, K. (1988). Human placenta $S$ adenosylmethionine protein carboxyl $O$-methyltransferase (protein methylase II), purification and characterization. International Journal of Biochemistry 20, 1107-1112.

Paolantonacci, P., Lawrence, F. \& Robert-Gero, M. (1985). Differential effect of sinefungin and its analogs on the multiplication of three Leishmania species. Antimicrobial Agents and Chemotherapy 28, 528-531.

Paolantonacci, P., Lawrence, F., Nolan, L. \& Robert-Gero, M. (1986). Protein methylation and protein methylases in Leishmania donovani and Leishmania tropica promastigotes. Molecular and Biochemical Parasitology 21, 47-54.

Paolantonacci, P., Lawrence, F., Nolan, L. L. \& Robert-Gero, M (1987). Inhibition of leishmanial DNA synthesis by sinefungin. Biochemical Pharmacology 36, 2813-2820.

Pays, E., Delauw, M. F., Laurent, M. \& Steinert, M. (1984). Possible DNA modification in GC dinucleotides of Trypanosome brucei telomeric sequences; relationship with antigen gene transcription. Nucleic Acids Research 12, 5235-5247.

Penketh, P. G., Krishnamurthy, S., Divo, A. A., Patton, C. L . \& SARTORELLI, A. C. (1990). Methylating agents as trypanocides. Journal of Medicinal Chemistry 33, 730-732.

Perry, K. L., Watkins, K. P. \& Agabian, N. (1987). Trypanosome mRNAs have unusual 'Cap 4' structures acquired by addition of a spliced leader. Proceedings of the National Academy of Sciences of the United States of America 84, 8190-8194.

RobBins, E. \& Boron, T. W. (1967). The cytoplasmic synthesis of histones in HeLa cells and its temporal relationship to DNA replication. Proceedings of the National Academy of Sciences of the United States of America 57, 409-416.

RoJAS, M. V. \& GaLANTI, N. (1990). DNA methylation in Trypanosoma cruzi. FEBS Letters 263, 113-116.

SHEPHERD, G. R., HARDiN, J. M. \& Noland, B. J. (1971). Methylation of lysine residues of histone fractions in synchronized mammalian cells. Archives of Biochemistry and Biophysics 143, 1-5.

TIDWell, T., Allfrey, V. G. \& Mirsky, A. E. (1968). The methylation of histones during regeneration of liver. Journal of Biological Chemistry 243, 707-715.

Trivedi, L., GuPTA, A., Paik, W. K. \& Kim, S. (1982). Purification and properties of protein methylase II from wheat germ. European Journal of Biochemistry 128, 349-354.

Ueland, P. M. (1982). Pharmacological and biochemical aspects of $S$ adenosylhomocysteine and $S$-adenosylhomocysteine hydrolase. Pharmacology Reviews 34, 223-253.

VAN WAARDE, A. (1987). What is the function of protein carboxyl methylation? Comparative Biochemistry and Physiology 86B, 423-438.

van WaARde, A. \& van Hoof, P. J. M. (1985). Pitfalls in the measurement of protein carboxyl methylation during chemotaxis of Dictyostelium discoideum. Biochimica et Biophysica Acta 840, 344-354.

YARLETT, N. \& BACCHI, C. J. (1988). Effect of DL- $\alpha$-difluoromethylornithine on methionine cycle intermediates in Trypanosoma brucei brucei. Molecular and Biochemical Parasitology 27, 1-10.

Zukerman, S. H., O'Dea, R. F., Olson, J. M. \& Douglas, D. S. (1982). Protein carboxylmethylation during in vitro culture of human peripheral blood monocytes and pulmonary alveolar macrophages. Molecular Immunology 19, 281-286. 